Journal of Economic, Business and Accounting (COSTING)

Volume 1 Nomor 2, Juni 2018

e-ISSN : 2597-5234

https://doi.org/10.31539/costing.v1i2.201

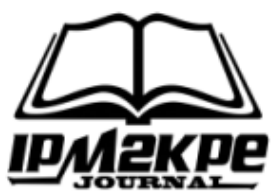

\title{
PENGARUH KOMPENSASI DAN KESELAMATAN KERJA TERHADAP \\ PRODUKTIVITAS KERJA KARYAWAN PADA PT. MUSIRAWAS LESTARI MAKMUR, KABUPATEN MUSI RAWAS
}

\section{THE EFFECT OF COMPENSATION AND SAFETY ON EMPLOYEE PRODUCTIVITY IN PT. MUSIRA WAS LESTARI MAKMUR MUSI RAWAS DISTRICT}

\author{
Fitria, Kartini \\ Sekolah Tinggi Ilmu Ekonomi Musirawas Lubuklinggau ${ }^{1,2}$ \\ fitria_cutte33@yahoo.com ${ }^{1,2}$
}

\begin{abstract}
Human Resources has been recognized as a central force that drives organizational dynamics. This study was conducted to determine the Effect of Compensation and Work Safety on Employee Productivity At PT. Musirawas Lestari Makmur Unit Tuah Negeri Musi Rawas Regency. The sample in this study amounted to 50 employees determined based on simple random sampling technique. Data analysis technique used is Multiple Linear Regression Analysis, Coefficient of Determination (R2), and Test F. From result of Multiple Regression Analysis obtained that compensation (X1) and safety (X2) give contribution of 83,2\% to work productivity $Y$ ). While the rest of $16.8 \%$ influenced by other variables. which is not included in this study. The results also indicate a significant influence between compensation and work safety on work productivity. For that the company needs to increase the compensation and employee safety to increase employee productivity.
\end{abstract}

Keywords: Compensation, Occupational Safety and Work Productivity.

\section{ABSTRAK}

Sumber Daya Manusia telah disadari merupakan kekuatan sentral yang menggerakkan dinamika organisasi. Penelitian ini dilakukan untuk mengetahui Pengaruh Kompensasi dan Keselamatan Kerja Terhadap Produktivitas Kerja Karyawan Pada PT. Musirawas Lestari Makmur Unit Tuah Negeri Kabupaten Musi Rawas. Sampel dalam penelitian ini berjumlah 50 orang karyawan yang ditentukan berdasarkan teknik simple random sampling. Teknik analisis data yang digunakan adalah Analisis Regresi Linier Berganda, Koefisien Determinasi $\left(\mathrm{R}^{2}\right)$, dan Uji F. Dari hasil Analisis Regresi Berganda diperoleh bahwa kompensasi $\left(\mathrm{X}_{1}\right)$ dan keselamatan kerja $\left(\mathrm{X}_{2}\right)$ memberikan sumbangan pengaruh sebesar $83,2 \%$ terhadap produktivitas kerja (Y). Sedangkan sisanya sebesar $16,8 \%$ dipengaruhi oleh variabel yang lain. yang tidak masuk dalam penelitian ini. Hasil penelitian juga menunjukkan adanya pengaruh yang signifikan antara kompensasi dan keselamatan kerja terhadap produktivitas kerja. Untuk itu perusahaan perlu meningkatkan kompensasi dan keselamatan kerja karyawan agar produktivitas karyawan juga meningkat.

Kata Kunci : Kompensasi, Keselamatan Kerja dan Produktivitas Kerja.

\section{PENDAHULUAN}

Dalam era persaingan global, keberadaan sumber daya manusia yang handal memiliki peran yang lebih strategis dibandingkan sumber daya yang lain. Sumber daya manusia adalah harta yang paling penting yang dimiliki oleh suatu organisasi, sedangkan manajemen yang efektif adalah kunci bagi keberhasilan suatu organisasi tersebut.

Sumber Daya Manusia telah disadari merupakan kekuatan sentral yang menggerakkan dinamika 
organisasi. Sumber Daya Manusia Berbeda dengan sumber daya lainnya, dimana manusia selalu berusaha mengembangkan Dirinya. Betapapun baiknya sumber daya lain yang dimiliki oleh perusahaan kalau tanpa didukung personalia yang dapat bekerja secara efektif dan efisien akan tetap tidak dapat mencapai tujuan perusahaan secara memuaskan bahkan dapat berakibat kegagalan. Untuk itu perusahaan harus dapat memanfaatkan Sumber Daya Manusia yang ada dengan cara menggerakan dan mengarahkan agar Sumber Daya Manusia yang ada untuk mampu bekerja dengan baik, sehingga tujuan yang ada dalam perusahaan dapat tercapai.

Sadar akan pentingnya sumber daya manusia bagi kelangsungan hidup dan kemajuan suatu organisasi, maka suatu organisasi harus memberikan perhatian khusus pada karyawan ini dan sudah sewajarnya organisasi memandang sumber daya manusia lebih dari sekedar aset organisasi dan menjadikan mitra dalam berusaha. Perusahaan harus dapat bersikap adil atas apa yang telah diberikan oleh karyawan kepada perusahaan, karena setiap karyawan berhak mendapatkan penghargaan dan perlakuan yang adil dari pimpinannya sebagai timbal balik atas jasa yang diberikannya, sehingga dapat mendorong para karyawan untuk lebih termotivasi dalam menjalankan kewajibannya sebagai seorang pekerja. Hubungan kerja yang saling menguntungkan antara perusahaan dan karyawan sangat diperlukan dalam rangka mendorong semangat kerja karyawan.

Sebuah organisasi terdiri atas berbagai elemen, salah satunya adalah sumber daya manusia selain adanya bahan baku, mesin/peralatan, metode/cara kerja dan modal. Melihat pentingnya sumber daya manusia bagi kelancaran operasional perusahaan, maka manusia merupakan aset paling penting yang harus ditingkatkan efisiensi dan kinerjanya. Untuk mencapai hal itu organisasi harus mampu menciptakan situasi dan kondisi yang mampu mendorong pegawai dalam bekerja secara optimal. Salah satu upaya yang dapat ditempuh organisasi yakni dengan memberikan kompensasi yang memuaskan kepada karyawan.

Manusia bekerja untuk memenuhi Dengan adanya pemberian kompensasi secara tepat dan adil maka kepuasan kerja dan prestasi kerja yang diharapkan oleh karyawan dapat terpenuhi. Produktivitas kerja karyawan yang rendah akan dapat menurunkan tingkat kualitas dan produktivitas kerja. Bagi karyawan, tingkat produktivitas kerja yang tinggi dapat memberikan keuntungan sendiri, seperti meningkatkan gaji, memperluas kesempatan untuk dipromosikan, menurunnya kemungkinan untuk didemosikan. Sebaliknya juga, jika tingkat produktivitas kerja karyawan tersebut rendah maka menunjukkan karyawan tersebut tidak kompeten dalam pekerjaannya, akibatnya ia sukar untuk dipromosikan ke jenjang pekerjaan yang tingkatannya lebih tinggi, dan memperbesar kemungkinan untuk didemosikan dan mengalami pemutusan hubungan kerja.

Oleh sebab itu, untuk dapat meningkatkan produktivitas tenaga kerja, upah atau gaji yang mereka terima harus memadai, mereka tidak hanya menerima kompensasi dalam bentuk gaji pokok saja , tetapi juga mendapatkan kompensasi dalam bentuk lain (tunjangan kesehatan, insentif, bonus, dll) untuk dapat meningkatkan kebutuhan fisik umumnya.

Keselamatan kerja termasuk salah satu program pemeliharaan yang ada di perusahaan. Pelaksanaan program keselamatan kerja bagi karyawan sangatlah penting karena bertujuan 
untuk menciptakan sistem keselamatan dan kesatuan kerja dengan melibatkan unsur manajemen, tenaga kerja, kondisi dan lingkungan kerja yang terintegrasi dalam rangka mengurangi kecelakaan.

Masalah perlindungan tenaga kerja akan semakin meningkat seiring dengan meningkatnya industrialisasi dan teknologi. Kondisi demikian tentunya menuntut perusahaan agar perlindungan tenaga kerja dapat semakin mantap ditinjau dari produktifitas, dan keselamatan kerja dalam bekerja yang dapat berpengaruh pada produktivitas kerja. Untuk mencapai produktivitas yang tinggi tidaklah mudah karena perusahaan juga menghadapi kendala antara lain berhubungan dengan sumber daya manusia. Manusia adalah faktor yang penting dalam proses produksi karena sumber daya manusia merupakan asset yang penting dalam suatu perusahaan.

Dengan adanya berbagai tuntutan tentang masalah kesehatan keselamatan kerja, maka perusahaan harus dapat memenuhi tanggung jawabnya dalam memberikan perlindungan pada karyawan dengan melakukan program-program tentang keselamayan kerja. Undang-undang Republik Indonesia Nomor 3 Tahun 1992, menyatakan bahwa sudah sewajarnya apabila tenaga kerja juga berperan aktif dan ikut bertanggung jawab atas pelaksanaan program pemeliharaan dan peningkatan kesejahteraan demi terwujudnya perlindungan tenaga kerja dan keluarganya dengan baik. Jadi, bukan hanya perusahaan saja yang bertanggung jawab dalam masalah ini, tetapi para karyawan juga harus ikut berperan aktif dalam hal ini agar dapat tercapai kesejahteraan bersama.

PT. Musirawas Lestari Makmur Unit II Kabupaten Musi Rawas merupakan perusahaan yang bergerak di bidang industry pengolahan kayu untuk plywood. PT. Musirawas Lestari Makmur Unit II mulai beroperasi dari bulan Mei 2007 sampai dengan sekarang dengan menyerap tenaga kerja sebanyak 203 orang dengan persentase tenaga lokal $80 \%$. Berdiri dan beroperasinya perusahaan berarti terciptanya lapangan kerja untuk tenaga lokal yang mampu memenuhi kebutuhannya.

Berdasarkan pengamatan

peneliti, karyawan PT. Musirawas Lestari Makmur Kabupaten Musi Rawas mengalami beberapa permasalahan yang terkait dengan pemberian kompensasi dan keselamatan kerja terhadap produktivitas kerja. Pertama, kompensasi dalam bentuk tunjangan kesehatan dan tunjangan hari raya untuk yang diberikan belum maksimal, kompensasi yang diberikan oleh perusahaan terkadang mengalami keterlambatan sehingga para karyawan tidak bersemangat dalam melaksanakan pekerjaaannya, selanjutnya pemberian kompensasi dianggap tidak adil dan tidak setingkat dengan apa yang dikerjakan oleh karyawan karena masih adanya kesenjangan antara sesama karyawan (Pekerjaan sama tapi kompensasi yang diberikan berbeda).

Selanjutnya keselamatan kerja, untuk tahun 2015 kecelakaan berat tidak pernah terjadi, tetapi kecelakaan ringan masih sering terjadi (seperti jari karyawan terjepit di mesin press drayer sehingga mengakibatkan luka pada jari karyawan tersebut). Hal ini disebabkan oleh kurangnya sosialisasi mengenai cara menggunakan alat kerja yang baik dan benar. Produktivitas kerja pegawai menurun karena kompensasi yang diberikan oleh perusahaan terlambat atau tidak cukup, maka kepuasan dalam bekerja akan berkurang dan semangat kerja akan terganggu. 
Produktivitas secara umum diartikan sebagai hubungan antara pengeluaran (barang-barang atau jasa) dengan masukan (tenaga kerja, bahan, uang). Produktivitas adalah ukuran efisiensi produktif. Suatu perbandingan antara hasil keluaran dan masukan. Masukan sering dibatasi dengan tenaga kerja, sedangkan keluaran diukur dalam kesatuan fisik, bentuk dan nilai (Sutrisno, 2014:100).

Tohardi (2002, dalam Sutrisno, 2014, h.100) mengemukakan bahwa produktivitas kerja merupakan sikap mental. Sikap mental yang selalu mencari perbaikan terhadap apa yang telah ada. Suatu keyakinan bahwa seseorang dapat melakukan pekerjaan lebih baik hari ini.

Ada tiga aspek utama yang perlu ditinjau dalam menjamin produktivitas yang tinggi, yaitu (a) aspek kemampuan manajemen tenaga kerja; (b) aspek efisiensi tenaga kerja; dan (c) aspek kondisi lingkungan pekerjaan. Ketiga aspek tersebut saling terkait dan terpadu dalam suatu sistem dan dapat diukur dengan berbagai ukuran yang relative sederhana (Singodimedjo, 2002 dalam Sutrisno, 2014, h.101). Produktivitas harus menjadi bagian yang tak boleh dilupakan dalam penyusunan strategi bisnis, yang mencakup bidang produksi, pemasaran, keuangan, dan bidang lainnya.

\begin{tabular}{|c|c|c|}
\hline & Men & Kusrian \\
\hline
\end{tabular}
mengemukakan bahwa produktivitas adalah perbandingan antara hasil yang dicapai dengan peran serta tenaga kerja per satuan waktu. Peran serta tenaga kerja disini adalah penggunaan sumber daya serta efisien dan efektif.

Dari definisi - definisi diatas, penulis menyimpulkan bahwa produktivitas kerja terdiri dari tiga aspek, yaitu : pertama, produktivitas adalah keluaran fisik per unit dari usaha produktif; kedua produktivitas kerja merupakan tingkat keefektifan dari manajemen industri di dalam penggunaan fasilitas-fasilitas untuk produksi; dan ketiga, produktivitas adalah keefektifan dari pengunaan tenaga kerja dan peralatan. Tetapi intinya semua mengarah pada tujuan yang sama, bahwa produktivitas kerja adalah rasio dari hasil kerja dengan waktu yang dibutuhkan untuk menghasilkan produk dari seorang tenaga kerja

Ada beberapa definisi kompensasi yang dikemukakan oleh para ahli, diantaranya Handoko (dalam Sutrisno, 2014:183) yang dimaksud kompensasi adalah segala sesuatu yang diterima karyawan sebagai balas jasa untuk kerja mereka. Kompensasi dapat diberikan dalam berbagai macam bentuk, seperti : dalam bentuk pemberian uang, pemberian material dan fasilitas, dan dalam bentuk pemberian kesempatan berkarir.

Menurut Wilson (2012:254) Kompensasi adalah sesuatu yang diterima karyawan atas jasa yang mereka sumbangkan pada pekerjaannya. Mereka menymbangkan apa yang menurut mereka berharga, baik tenaga maupun pengetahuan yang dimiliki.

Menurut Hasibuan (2014:118) "kompensasi adalah semua pendapatan yang berbentuk uang, barang langsung atau tidak langsung yang diterima karyawan sebagai imbalan atas jasa yang diberikan kepada perusahaan".

Menurut Thomas (dalam Suwatno dan Doni, 2013: 220) Kompensasi adalah setiap bentuk pembayaran yang diberikan kepada karyawan sebagai bentuk pertukaran pekerjaan yang mereka berikan kepada majikan. Sedangkan menurut Flippo (dalam Suwatno dan Doni, 2013: 220) kompensasi merupakan pemberian imbalan jasa yang layak dan adil kepada karyawan - karyawan karena 
mereka telah memberi sumbangan kepada pencapaian organisasi. Pemberian kompensasi sangat penting bagi karyawan, karena besar kecilnya kompensasi merupakan ukuran terhadap produktivitas kerja karyawan.

$$
\text { Berdasarkan pengertian- }
$$

pengertian diatas maka dapat menyimpulkan bahwa kompensasi merupakan bentuk penghargaan atau balas jasa yang diberikan oleh perusahaan kepada karyawannya baik yang berbentuk finansial maupun barang dan jasa pelayanan agar karyawan merasa dihargai dalam bekerja. Pemberian kompensasi merupakan salah satu pelaksanaan fungsi MSDM yang berhubngan dengan semua jenis pemberian penghargaan individual sebagai pertukaran dalam melakukan tugas organisasi.

$$
\text { Menurut Yani }
$$

Keselamatan kerja adalah keselamatan yang berhubungan dengan aktivitas kerja manusia baik pada industry manufaktur, yang melibatkan mesin, peralatan, penangan material, pesawat uap, bejana bertekanan, alat kerja, proses dan pengolahannya, landasan tempat kerja dan lingkungannya serta cara - cara melakukan pekerjaan, maupun industry jasa, yang melibatkan peralaatan berteknolobi canggih, seperti lift, escalator, peralatan pembersih gedung, sarana transportasi, dan lain-lain.

Swasto (2011:107 dalam Bayu Ramdan, dkk, 2014) mengemukakan bahwa, "keselamatan kerja menyangkut segenap proses perlindungan tenaga kerja terhadap kemungkinan adanya bahaya yang timbul dalam lingkungan pekerjaan. Pada dasarnya usaha untuk memberikan perlindungan keselamatan kerja menurut Soeprihatno (2002: 48) ada 2 (dua):

a. Usaha preventif atau mencegah

Preventif atau mencegah berarti mengendalikan atau menghambat sumber bahaya yang terdapat di tempat kerja sehingga dapat mengurangi atau tidak menimbulkan bahaya bagi para karyawan.

Langkah-langkah pencegahan itu dapat dibedakan yaitu:

1) Subtitusi (mengganti alat/sarana yang kurang/tidak berbahaya).

2) Isolasi (memberi isolasi/alat pemisah terhadap sumber bahaya).

3) Pengendalian secara teknis terhadap sumber-sumber bahaya.

4) Pemakaian alat pelindung perorangan (eye protection, safety hat and cap, gas respirator, dust respirator, dan lain-lain).

5) Petunjuk dan peringatan di tempat kerja.

6) Latihan dan pendidikan keselamatan dan kesehatan kerja

b. Usaha represif atau kuratif

Kegiatan yang bersifat kuratif berarti mengatasi kejadian atau kecelakaan yang

disebabkan oleh sumber-sumber bahaya yang terdapat di tempat kerja. Pada saat terjadi kecelakaan atau kejadian lainnya sangat dirasakan arti pentingnya persiapan baik fisik maupun mental para karyawan sebagai suatu kesatuan atau team kerja sama dalam rangka mengatasi dan menghadapi.

Berdasarkan latar belakang diatas, maka peneliti tertarik untuk melakukan penelitian dengan judul : Pengaruh Kompensasi dan Keselamatan Kerja Terhadap Produktivitas Kerja karyawan Pada Sekretariat PT. Musirawas Lestari Makmur Unit Tuah Negeri Kabupaten Musi Rawas.

\section{METODE PENELITIAN \\ Lokasi Penelitian}

Lokasi yang dijadikan tempat penelitian ini adalah PT. Musirawas Lestari Makmur Unit Tuah Negeri yang 
beralamat di Desa Lubuk Rumbai Kabupaten Musi Rawas.

\section{Populasi dan Sampel}

Populasi adalah wilayah
generalisasi yang terdiri atas obyek/subyek yang mempunyai kuantitas dan karekteristik tetentu yang ditetapkan oleh peneliti untuk dipelajari dan kemudian ditarik kesimpulannya (Sugiyono, 2014:61). Populasi dalam penelitian ini seluruh objek penelitian ini seluruh objek penelitian berjumlah 203 orang karyawan.

Sampel adalah sebagian dari jumlah dan karateristik yang dimiliki oleh populasi tersebut (Sugiyono, 2014:62). Peneliti mengambil jumlah sampel dengan menggunakan rumus Arikunto (2006:134) apabila subjek kurang dari 100 lebih baik diambil semuanya tetapi jika lebih dapat diambil antara $10 \%$ - $15 \%$ atau $20 \%$ - $25 \%$ tergantung dari kemampuan dari kemampuan peneliti dilihat dari waktu, tenaga dan dana. Jumlah sampel ditetapkan dengan teknik sampling. Dari jumlah populasi peneliti mengambil sampel sebesar $25 \%$ dari populasi. Jadi sampel dalam penelitian ini berjumlah 50 orang karyawan. Metode sampel yang digunakan yaitu metode Simple Random Sampling. Simple Random Sampling adalah cara pengambilan sampel dengan cara acak dari jumlah polulasi dengan menggunakan acak tanpa memperhatikan strata (tingkatan) dalam anggota populasi tersebut (Riduwan,2004:10)

\section{Teknik Pengumpulan Data}

Penelitian ini menggunakan tiga teknik pengumpulan data yang di gunakan yaitu :

\section{a. Observasi}

Pada langkah ini yang dilakukan peneliti adalah dengan mengadakan pengamatan terhadap objek yang akan di teliti, yang ada kaitannya dengan pokok bahasan yang dikaji yaitu kompensasi lingkungan kerja terhadap produktivitas kerja (Sugiyono, 2014:145).

\section{b. Kuisioner}

Dengan cara membagikan kuisioner yang telah disiapkan oleh responden dalam

hal ini karyawan PT. Musirawas Lestari Makmur Unit Tuah Negeri Kabupaten Musi Rawas (Sugiyono, 2014: 142).

\section{c. Dokumentasi}

Dengan cara mencatat keterangan dan dokumen yang resmi. Teknik ini digunakan dalam rangka mendukung data yang di peroleh baik melaui observasi maupun kuisioner (Sugiyono, 2014:240).

\section{Uji Validitas dan Reliabilitas}

\section{a. Uji Validitas}

Validitas adalah suatu ukuran yang menujukkan tingkat - tingkat kevalidan atau kesahihan sesuatu instrumen. Suatu instrumen yang valid atau sahih mempunyai validitas tinggi. Sebaliknya, instrumen yang kurang valid berarti memiliki validitas rendah (Arikunto, 2006:168).

Untuk menghitung korelasi pada uji validitas menggunakan korelasi item total. Menurut Sugiono (2014:188) dengan rumus sebagai berikut:

Keterangan :

$$
r_{x y}=\frac{\sum X Y}{\sqrt{\sum^{2} X^{2}}}
$$

$r_{x y} \quad=$ Koefisien Korelasi

$N \quad=$ Banyaknya Sampel

$\sum X \quad=$ Jumlah skor keseluruhan untuk item pertanyaan

$\sum Y \quad=$ Jumlah skor keseluruhan untuk semua item pertanyaan

\section{b. Uji Reliabilitas}

Reliabilitas menunjuk pada suatu pengertian bahwa suatu instrumen 
cukup dapat dipercaya untuk digunakan sebagai alat pengumpul data karena instrumen tersebut sudah baik. Instrumen yang baik tidak akan bersifat tendensius mengarahkan responden untuk memilih jawaban - jawaban tertentu. Instrumen yang sudah dapat dipercaya, yang reliabel akan menghasilkan data yang dapat dipercaya juga (Arikunto, 2006 :178).

Pengujian reliabilitas kuesioner pada penelitian ini peneliti menggunakan metode Alpha Cronbach (a) menurut Sugiyono (2014:177) dengan rumus sebagai berikut:

$$
R=\alpha=R=\frac{N}{N-1}\left(\frac{S^{2}\left(1-\Sigma S_{i}^{2}\right.}{S^{2}}\right)
$$

Keterangan :

$\alpha=$ Koefisien Reliabilitas Alpha

Cronbach

$S^{2}=$ Varians skor keseluruhan

$S_{i}^{2}=$ Varians masing-masing item

\section{Uji Statistik}

\section{a. Regresi Linear Sederhana}

Analisis regresi linier sederhana digunakan untuk mengetahui pengaruh antara satu variabel independen dengan satu variabel dependen. Analisis ini juga memprediksikan nilai dari variabel dependen apabila nilai variabel independen mengalami kenaikan atau penurunan dan untuk mengetahui arah hubungan antara variabel independen dengan variabel dependen apakah positif atau negatif.

Persamaan regresi linier sederhana adalah :

$$
\mathrm{Y}=\mathrm{a}+\mathrm{bX}
$$

(Sugiyono, 2014, h. 188)

Keterangan :

$\mathrm{Y}=$ Variabel dependen yang diprediksi

$\mathrm{X}=$ Variabel independen

$\mathrm{a}=$ Nilai konstanta

$\mathrm{b}=$ Koefisien regresi.

\section{b. Koefisien Korelasi}

Analisis koefisien korelasi parsial digunakan untuk mengetahui kuatnya hubungan antara satu variabel independen terhadap variabel dependen. Arahnya dinyatakan dalam bentuk hubungan positif atau negatif, sedangkan kuat atau lemahnya hubungan dinyatakan dalam besarnya koefisien korelasi.

Menurut Sugiyono (2014:274) analisis korelasi dapat diformulasikan sebagai berikut :

$$
\mathrm{r}=\frac{\mathrm{n} \sum \mathrm{xy}-\left(\sum \mathrm{x}\right)\left(\sum \mathrm{y}\right)}{\sqrt{\left\{\mathrm{n} \sum x^{2}-\left(\sum x\right)^{2}\right\}\left\{\mathrm{n} \sum y^{2}-\right.}}
$$

Keterangan :

$r=$ Korelasi antara variabel $\mathrm{X}$ dengan $\mathrm{Y}$

$\mathrm{n}=$ Banyaknya sampel

$\mathrm{x}=$ Nilai variabel $\mathrm{X}$

$\mathrm{y}=$ Nilai variabel $\mathrm{Y}$

c. Uji t

Uji t digunakan untuk menguji pengaruh variabel independen secara parsial terhadap variabel dependen, apakah pengaruhnya signifikan atau tidak. (Priyatno, 2013, h.50). Variabel independen yang terdiri atas kompensasii dan keselamatan kerja terhadap produktivitas kerja yang merupakan variabel dependen. Prosedur pengujian hipotesis dengan uji $\mathrm{t}$ :

1. Menentukan hipotesis

2. Menentukan taraf signifikansi, taraf signifikansi menggunakan 0,05

3. Membandingkan t-hitung dan t-tabel

4. Pengambilan keputusan

- Jika $t_{\text {hitung }} \leq t_{\text {tabel }}$ maka $\mathrm{H}_{\mathrm{o}}$ diterima.

- Jika $t_{\text {hitung }}>\mathrm{t}_{\text {tabel }}$ maka $\mathrm{H}_{\mathrm{o}}$ di tolak

\section{d. Analisis Regresi Linear Berganda}

Model analisa yang di gunakan peneliti dalam permasalahan yang ada dalam penelitian ini adalah untuk membuktikan ada atau tidaknya hubungan fungsional atau hubungan 
kuasal antara dua variabel bebas atau lebih dengan satu variabel terikat.

$$
Y=a+b_{1} X_{1}+b_{2} X_{2}
$$

Dimana :

$$
\begin{aligned}
& \mathrm{Y}=\text { Produktivitas Kerja } \\
& \mathrm{X}_{1}=\text { Kompensasi } \\
& \mathrm{X}_{2}=\text { Keselamatan Kerja } \\
& \mathrm{a}=\text { Titik Potong } \\
& \mathrm{b}_{1}, \mathrm{~b}_{2}=\text { Koefisien Regresi }
\end{aligned}
$$

\section{e. Koefisien Determinasi $\left(\mathbf{R}^{2}\right)$}

Analisis regresi berganda adalah meramalkan bagaimana keadaan naik turunnya variabel dependen, bila dua atau lebih variabel independen sebagai faktor predicator dimanipulasi (dinaik turunkan nilainya) (Sugiyono, 2013:275). Koefisien determinasi $\left(\mathrm{R}^{2}\right)$ pada intinya mengukur seberapa jauh kemampuan model dalam menerangkan variasi variabel bebas (dependen). Nilai koefisien determinasi adalah di antara nol dan satu. Nilai $\mathrm{R}^{2}$ yang kecil berarti kemampuan variabel-variabel bebas dalam menjelaskan variasi variabel terikat amat terbatas. Nilai $\mathrm{R}^{2}$ yang mendekati satu berarti variabel-variabel bebas memberikan hampir semua informasi yang dibutuhkan untuk memprediksi variasi variabel terikat.

Formulasi persamaan uji korelasi ganda adalah sebagai berikut:

$$
\sqrt{\frac{\left(r y x_{1}\right)^{2}+\left(r y x_{2}\right)^{2}-2 \cdot\left(r x y_{1}\right) \cdot\left(r y x_{2}\right) \cdot\left(r x_{1} x_{2}\right)}{1-\left(r x_{1} x_{2}\right)}}
$$

Dimana :

$\mathrm{Ry} \cdot \mathrm{X} 1, \mathrm{x} 2$ : korelasi variabel $\mathrm{X}_{1}$ dengan $\mathrm{X}_{2}$ secara bersama-sama

$\operatorname{ryx}_{1}$ : korelasi sederhana antara $X_{1}$ dengan $\mathrm{Y}$

$\operatorname{ryx}_{2}$ : korelasi sederhana antara $\mathrm{X}_{2}$ dengan $\mathrm{Y}$

$\mathrm{rx}_{1} \mathrm{x}_{2}$ : korelasi sederhana antara $\mathrm{X}_{1}$ dengan $\mathrm{X}_{2}$

\section{f. Uji $F$}

Uji $\mathrm{F}$ dilakukan untuk menguji signifikansi dengan membandingkan
$\mathrm{F}_{\text {hitung dengan }} \mathrm{F}_{\text {tabel }}$ (Riduwan dan Sunarto, 2009, 110).

Rumus :

$$
\mathrm{F}_{\text {hitung }}=\frac{R^{2}(n-m-1)}{m\left(1-R^{2}\right)}
$$

Dimana :

$\mathrm{R}^{2} \quad$ : Nilai Regresi

$\mathrm{m}$ : Jumlah variabel bebas

$\mathrm{n} \quad$ : Jumlah responden

Jika :

- $F_{\text {hitung }} \geq F_{\text {tabel }}$, maka tolak Ho artinya signifikan

- $F_{\text {hitung }} \leq \mathrm{F}_{\text {tabel}}$, maka terima Ho artinya tidak signifikan

Pengujian dengan uji $\mathrm{F}$ variasinya adalah dengan membandingkan $F_{\text {hitung }}$ $\left(F_{h}\right)$ dengan $F_{\text {tabel }}\left(F_{t}\right)$ pada $\alpha=0,05$ apabila hasil perhitungannya menunjukkan :

a. $\mathrm{F}_{\mathrm{h}}>\mathrm{F}_{\mathrm{t}}$, maka $\mathrm{H}_{0}$ ditolak dan $\mathrm{h}_{\mathrm{a}}$ diterima

Artinya variasi dari model regresi berhasil menerangkan variasi variabel bebas secara keseluruhan, sejauh mana pengaruhnya terhadap variabel tidak bebas (variabel terikat).

b. $\mathrm{F}_{\mathrm{h}}<\mathrm{F}_{\mathrm{t}}$, maka $\mathrm{H}_{0}$ diterima dan $\mathrm{H}_{\mathrm{a}}$ ditolak

Artinya variasi dari model regresi tidak berhasil menerangkan variasi variabel bebas secara keseluruhan, sejauh mana pengaruhnya terhadap variabel tidak bebas (variabel terikat).

HASIL DAN PEMBAHASAN

a. Hasil Uji Validitas dan Reliabilitas

Tabel 1

Hasil Uji Validitas $\left(\mathbf{X}_{1}\right)$

\begin{tabular}{ccccc}
\hline No & Item & $\mathbf{r}_{\text {hitung }}$ & $\begin{array}{c}\mathbf{r}_{\text {tabel }} \\
\mathbf{a = 0 , 0 5} \\
\mathbf{n = 3 0}\end{array}$ & Keterangan \\
\hline 1. & Pertanyaan 1 & 0,607 & 0,361 & Valid \\
\hline 2. & Pertanyaan 2 & 0,726 & 0,361 & Valid \\
\hline 3. & Pertanyaan 3 & 0,695 & 0,361 & Valid \\
\hline 4. & Pertanyaan 4 & 0,691 & 0,361 & Valid \\
\hline
\end{tabular}




\begin{tabular}{ccccc}
\hline 5. & Pertanyaan 5 & 0,664 & 0,361 & Valid \\
\hline 6. & Pertanyaan 6 & 0,539 & 0,361 & Valid \\
\hline 7. & Pertanyaan 7 & 0,560 & 0,361 & Valid \\
\hline 8. & Pertanyaan 8 & 0,485 & 0,361 & Valid \\
\hline 9. & Pertanyaan 9 & 0,446 & 0,361 & Valid \\
\hline 10. & Pertanyaan 10 & 0,562 & 0,361 & Valid \\
\hline
\end{tabular}

\section{Tabel 2}

Hasil Uji Validitas $\left(\mathbf{X}_{2}\right)$

\begin{tabular}{ccccc}
\hline No & Item & $\mathbf{r}_{\text {hitung }}$ & $\begin{array}{c}\mathbf{r}_{\text {tabel }} \\
\mathbf{a = 0 , 0 5} \\
\mathbf{n = 3 0}\end{array}$ & Keterangan \\
\hline 1. & Pertanyaan 1 & 0,697 & 0,361 & Valid \\
\hline 2. & Pertanyaan 2 & 0,629 & 0,361 & Valid \\
\hline 3. & Pertanyaan 3 & 0,724 & 0,361 & Valid \\
\hline 4. & Pertanyaan 4 & 0,710 & 0,361 & Valid \\
\hline 5. & Pertanyaan 5 & 0,622 & 0,361 & Valid \\
\hline 6. & Pertanyaan 6 & 0,669 & 0,361 & Valid \\
\hline 7. & Pertanyaan 7 & 0,480 & 0,361 & Valid \\
\hline 8. & Pertanyaan 8 & 0,544 & 0,361 & Valid \\
\hline 9. & Pertanyaan 9 & 0,572 & 0,361 & Valid \\
\hline 10. & Pertanyaan 10 & 0,506 & 0,361 & Valid \\
\hline & &
\end{tabular}

\section{Tabel 3}

\section{Hasil Uji Validitas Variabel (Y)}

\begin{tabular}{ccccc}
\hline No & Item & $\mathbf{r}_{\text {hitung }}$ & $\begin{array}{c}\mathbf{r}_{\text {tabel }} \\
\mathbf{a = 0 , 0 5} \\
\mathbf{n = 3 0}\end{array}$ & Keterangan \\
\hline 1. & Pertanyaan 1 & 0,628 & 0,361 & Valid \\
\hline 2. & Pertanyaan 2 & 0,549 & 0,361 & Valid \\
\hline 3. & Pertanyaan 3 & 0,571 & 0,361 & Valid Mode \\
\hline 4. & Pertanyaan 4 & 0,550 & 0,361 & Valid \\
\hline 5. & Pertanyaan 5 & 0,432 & 0,361 & Valid \\
\hline 6. & Pertanyaan 6 & 0,598 & 0,361 & Valid \\
\hline 7. & Pertanyaan 7 & 0,577 & 0,361 & Valid \\
\hline 8. & Pertanyaan 8 & 0,527 & 0,361 & Valid \\
\hline 9. & Pertanyaan 9 & 0,653 & 0,361 & Valid \\
\hline 10. & Pertanyaan 10 & 0,546 & 0,361 & Valid \\
\hline & & & &
\end{tabular}

Dari tabel diatas dapat dilihat bahwa hasil pengujian validitas instrumen menunjukkan bahwa seluruh pernyataan valid karena nilai rhitung lebih besar dari nilai rtabel dan bernilai positif.

\section{Tabel 4}

\section{Hasil Uji Reabiilitas}

\begin{tabular}{|c|c|c|c|}
\hline $\begin{array}{c}\text { Variabel } \\
\text { Penelitian }\end{array}$ & $\begin{array}{c}\text { Nilai } \\
\text { Cronbach's } \\
\text { Alpha }\end{array}$ & $\begin{array}{c}\text { Nilai } \mathbf{r}_{\text {tabel }} \\
\mathbf{n}=\mathbf{3 0}\end{array}$ & Keterangan \\
\hline
\end{tabular}

\begin{tabular}{cccc}
\hline $\begin{array}{c}\text { Kompensasi } \\
\left(\mathrm{X}_{1}\right)\end{array}$ & 0,868 & 0,361 & Reliabel \\
\hline $\begin{array}{c}\text { Keselamatan } \\
\text { Kerja }\left(\mathrm{X}_{2}\right)\end{array}$ & 0,879 & 0,361 & Reliabel \\
\hline $\begin{array}{c}\text { Produktivitas } \\
\text { Kerja (Y) }\end{array}$ & 0,853 & 0,361 & Reliabel \\
\hline \multicolumn{1}{c}{ Dari tabel diatas } & diketahui hasil
\end{tabular}

Dari tabel diatas diketahui hasil uji reabilitas variabel Kompensasi $\left(\mathrm{X}_{1}\right)$ sebesar 0,868, variabel Keselamatan Kerja $\left(\mathrm{X}_{2}\right)$ sebesar 0,879 dan variabel Produktivitas Kerja (Y) sebesar 0,853. Nilai $r_{\text {tabel }}$ dengan $\mathrm{n}=30, \alpha=5 \%$ adalah sebesar 0,361. Hal ini berarti item item pertanyaan pada variabel Kompensasi $\left(\mathrm{X}_{1}\right)$, Keselamatan Kerja $\left(\mathrm{X}_{2}\right)$ dan variabel Produktivitas Kerja (Y) tersebut reliabel dan dapat dijadikan sebagai alat ukur pada analisis selanjutnya.

\section{b. Hasil Analisis Regresi Linier Sederhana}

\section{Tabel 5}

Hasil Analisis Regresi Linier Sederhana Kompensasi $\left(\mathbf{X}_{1}\right)$ terhadap Produktivitas Kerja (Y)

\begin{tabular}{|c|c|c|c|c|c|}
\hline \multicolumn{6}{|c|}{ Coefficients $^{\mathrm{a}}$} \\
\hline & $\begin{array}{r}\text { Unstanc } \\
\text { Coeffi }\end{array}$ & $\begin{array}{l}\text { ardized } \\
\text { cients }\end{array}$ & $\begin{array}{c}\text { Standardized } \\
\text { Coefficients }\end{array}$ & & \\
\hline el & B & $\begin{array}{c}\text { Std. } \\
\text { Error }\end{array}$ & Beta & $\mathrm{t}$ & Sig. \\
\hline Constant) & 9.342 & 2.138 & & 4.370 & .000 \\
\hline $\begin{array}{l}\text { KOMPENSASI } \\
\text { X1) }\end{array}$ & .760 & .053 & .901 & $\begin{array}{r}14.36 \\
5\end{array}$ & .000 \\
\hline
\end{tabular}
perhitungan regresi linier sederhana, maka diperoleh nilai $b=0,760$ sedangkan nilai $a=9,342$. Kemudian nilai tersebut dimasukkan kedalam persamaan regresi linear sederhana sebagai berikut :

$$
\begin{aligned}
& Y=a+b X_{1} \\
& Y=9,342+0,760 X_{1}
\end{aligned}
$$

Arti persamaan tersebut adalah :

1) Nilai konstanta sebesar $a=9,342$ menyatakan bahwa jika kompensasi tidak ada perubahan atau nilainya nol maka nilai variabel Produktivitas Kerja adalah sebesar 9,342. 
2) Koefisien regresi kompensasi sebesar $b=0,760$ menyatakan bahwa setiap peningkatan kompensasi sebesar satu satuan maka hal tersebut akan meningkatkan produktivitas kerja sebesar 0,760 .

\section{Tabel 6}

Hasil Analisis Regresi Linier

Sederhana Keselamatan Kerja (X2) terhadap Produktivitas Kerja (Y)

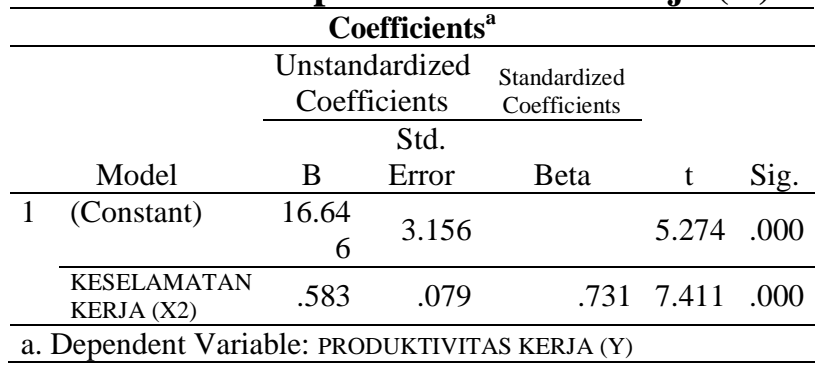

\section{Sumber : Hasil Penelitian}

Dari tabel diatas dapat diketahui hasil perhitungan regresi linier sederhana, maka diperoleh nilai $\mathrm{b}=0,583$ sedangkan nilai $\mathrm{a}=16,646$. Kemudian nilai tersebut dimasukkan kedalam persamaan regresi linear sederhana sebagai berikut :

$$
\begin{aligned}
& Y=a+b X_{2} \\
& Y=16,646+0,583 X_{2}
\end{aligned}
$$

Arti persamaan tersebut adalah :

1) Nilai konstanta sebesar $a=16,646$ menyatakan bahwa jika keselamatan kerja tidak ada perubahan atau nilainya nol maka nilai variabel produktivitas kerja adalah sebesar 16,646 .

2) Koefisien regresi keselamatan kerja sebesar $b=0,583$ menyatakan bahwa setiap peningkatan keselamatan kerja sebesar satu satuan maka hal tersebut akan meningkatkan produktivitas kerja sebesar 0,583. Sebaliknya, setiap penurunan keselamatan kerja sebesar satu satuan maka hal tersebut akan menurunkan produktivitas kerja sebesar 0,583.

\section{c. Hasil Koefisien Korelasi Tabel 7}

Hasil Analisis Koefisien Korelasi (R) Kompensasi $\left(\mathrm{X}_{1}\right)$ terhadap Produktivitas Kerja (Y)

\begin{tabular}{|c|c|c|c|c|}
\hline \multicolumn{5}{|c|}{ Model Summary } \\
\hline Model & $\mathrm{R}$ & $\begin{array}{c}\mathrm{R} \\
\text { Square }\end{array}$ & $\begin{array}{l}\text { Adjusted } \\
\text { R Square }\end{array}$ & $\begin{array}{l}\text { Std. Error } \\
\text { of the } \\
\text { Estimate }\end{array}$ \\
\hline 1 & $.901^{\mathrm{a}}$ & .811 & .807 & 1.295 \\
\hline a. $\operatorname{Pr}$ & s: $\left(C_{C}\right.$ & stant), & OMPENS & SI (X1) \\
\hline
\end{tabular}
Model Summary

\section{Sumber : Hasil Penelitian}

Dari tabel diatas diperoleh angka $\mathrm{R}$ sebesar 0,901. Hal ini menunjukkan bahwa Kompensasi $\left(\mathrm{X}_{1}\right)$ dengan Produktivitas Kerja (Y) mempunyai hubungan sangat kuat. Sedangkan arah hubungan adalah positif karena nilai $\mathrm{R}$ positif.

Nilai R (Koefisien Korelasi) dapat dilihat pada tabel dibawah ini :

\section{Tabel 8}

Tabel Nilai R ( Koefisien Korelasi)

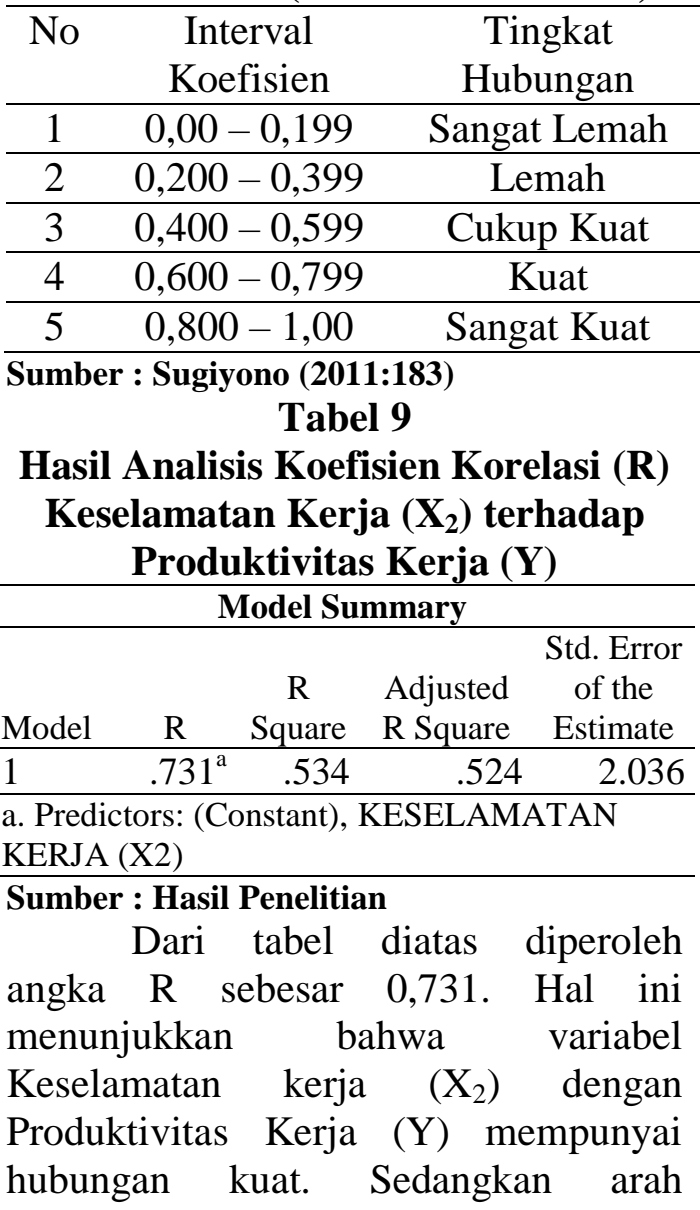


hubungan adalah positif karena nilai $\mathrm{R}$ positif.

\section{d. Hasil Uji t}

Tabel 10

Hasil Uji t Kompensasi $\left(X_{1}\right)$ dan

Keselamatan Kerja $\left(\mathbf{X}_{2}\right)$ terhadap Produktivitas Kerja (Y)

\begin{tabular}{cccc}
\hline \multicolumn{1}{c}{ Variabel } & $\begin{array}{c}\text { Nilai t- } \\
\text { hitung }\end{array}$ & $\begin{array}{c}\text { Nilai t- } \\
\text { tabel }\end{array}$ & Keterangan \\
\hline $\begin{array}{c}\text { Kompensasi } \\
\left(\mathrm{X}_{1}\right)\end{array}$ & 14,365 & 1,29871 & Signifikan \\
\hline $\begin{array}{l}\text { Keselamatan } \\
\text { Kerja }\left(\mathrm{X}_{2}\right)\end{array}$ & 7,411 & 1,29871 & Signifikan \\
\hline
\end{tabular}

Sumber : Hasil Penelitian

Dari tabel diatas dapat diketahui hasil thitung menunjukkan bahwa variabel kompensasi $\left(\mathrm{X}_{1}\right)$ dan variable keselamatan kerja $\left(\mathrm{X}_{2}\right)$ mempunyai nilai $t_{\text {hitung }}$ lebih besar dibandingkan dengan nilai $t_{\text {tabel }}$ pada taraf nyata sebesar 1,29871 atau dapat dikatakan kompensasi $\left(\mathrm{X}_{1}\right)$ dan keselamatan kerja $\left(\mathrm{X}_{2}\right)$ berpengaruh signifikan terhadap produktivitas kerja (Y).

e. Hasil Uji Regresi Linier Berganda Tabel 11

Hasil Analisis Regresi Linier Berganda Kompensasi $\left(\mathbf{X}_{1}\right)$ dan Keselamatan Kerja $\left(\mathbf{X}_{2}\right)$ terhadap Produktivitas Kerja (Y)

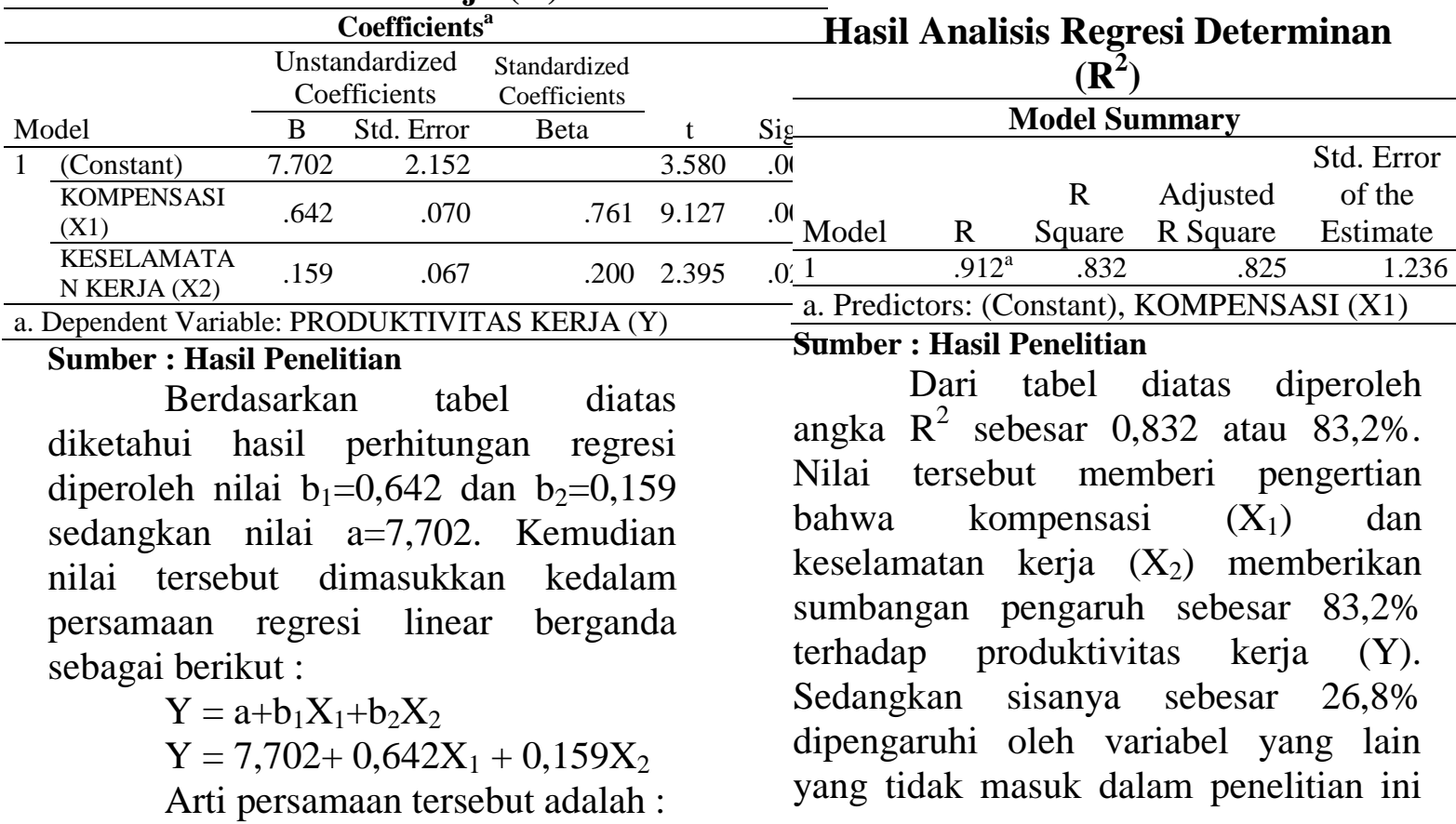

a. Nilai konstanta sebesar a $=7,702$ menyatakan bahwa jika kompensasi dan keselamatan kerja tidak ada perubahan atau nilainya nol maka nilai variabel produktivitas kerja adalah sebesar 7,702.

b. Koefisien regresi kompensasi sebesar $\mathrm{b}_{1}=0,642$ menyatakan bahwa setiap peningkatan kompensasi sebesar satu satuan maka hal tersebut akan meningkatkan produktivitas kerja sebesar 0,642. Sebaliknya, setiap penurunan kompensasi sebesar satu satuan maka hal tersebut akan menurunkan produktivitas kerja sebesar 0,642.

c. Koefisien regresi keselamatan kerja sebesar $b_{2}=0,159$ menyatakan bahwa setiap peningkatan keselamatan kerja sebesar satu satuan maka hal tersebut akan meningkatkan produktivitas kerja sebesar 0,159. Sebaliknya, setiap penurunan keselamatan kerja sebesar satu satuan maka hal tersebut akan menurunkan produktivitas kerja sebesar 0,159.

\section{f. Hasil Uji Koefisien Determinasi $\left(\mathbf{R}^{2}\right)$}

\section{Tabel 12}


seperti motivasi, iklim organisasi, lingkungan kerja, semangat kerja, dll.

g. Hasil Uji F

Dari analisa output regresi dapat diketahui nilai F seperti tabel berikut :

Tabel 13

Hasil Uji F

\begin{tabular}{|c|c|c|c|c|c|}
\hline \multicolumn{6}{|c|}{ ANOVA $^{a}$} \\
\hline Model & $\begin{array}{l}\text { Sum of } \\
\text { Squares }\end{array}$ & df & $\begin{array}{c}\text { Mean } \\
\text { Square }\end{array}$ & $\mathrm{F}$ & Sig. \\
\hline 1 Regression & 355.029 & 2 & 177.515 & 116.215 & $.000^{\mathrm{b}}$ \\
\hline Residual & 71.791 & 47 & 1.527 & & \\
\hline Total & 426.820 & 49 & & & \\
\hline
\end{tabular}

a. Dependent Variable: PRODUKTIVITAS KERJA (Y)

b. Predictors: (Constant), KESELAMATAN KERJA (X2), KOMPENSASI (X1)

Sumber : Hasil Penelitian

Dengan menggunakan tingkat keyakinan 95\%, a=5\%, df1 (jumlah variabel-1)=2 dan df2 (n-k-1) atau(50-2$1)=47$. Nilai $F_{\text {hitung }}$ adalah sebesar 116,215 dengan tingkat signifikansi 0,000. Menurut Sugiyono (2014, h.295) jika $F_{\text {hitung }}>F_{\text {tabel }}$ maka Ho ditolak dan Ha diterima. Sebaliknya jika $F_{\text {hitung }}<$ $F_{\text {tabel }}$ maka Ho diterima dan Ha ditolak. Pada penelitian ini ternyata $F_{\text {hitung }}$ $\left(116,215>F_{\text {tabel }}(3,20)\right.$, artinya Ho ditolak dan $\mathrm{Ha}$ diterima. Hal ini menunjukkan ada pengaruh yang signifikan antara kompensasi dan keselamatan kerja terhadap produktivitas kerja.

h. Pengaruh Kompensasi (X1) dan keselamatan Kerja (X2) Produktivitas Kerja Pegawai (Y) Pada PT. Musirawas Lestari Makmur Kabupaten Musi Rawas

Dari persamaan regresi $\mathrm{Y}=$ $7,702+0,642 X_{1}+0,159 X_{2}$ menggunakan nilai konstanta sebesar $\mathrm{a}=7,702$ yang artinya bahwa jika kompensasi dan keselamatan kerja tidak ada perubahan atau nilainya nol maka nilai variabel produktivitas kerja adalah sebesar 7,702.

Nilai Koefisien regresi kompensasi sebesar $b_{1}=0,642$ menyatakan bahwa setiap peningkatan kompensasi sebesar satu satuan maka hal tersebut akan meningkatkan kinerja pegawai sebesar 0,642. Sebaliknya, setiap penurunan kompensasi sebesar satu satuan maka hal tersebut akan menurunkan kinerja pegawai sebesar 0,642 .

Koefisien regresi keselamatan kerja sebesar $b_{2}=0,159$ menyatakan bahwa setiap peningkatan keselamatan kerja sebesar satu satuan maka hal tersebut akan meningkatkan produktivitas kerja sebesar 0,159. Sebaliknya, setiap penurunan keselamatan kerja sebesar satu satuan maka hal tersebut akan menurunkan produktivitas kerja sebesar 0,159 .

Nilai koefisien determinasi atau $\mathrm{R}^{2}$ sebesar 0,832 atau $83,2 \%$. Nilai tersebut memberi pengertian bahwa kompensasi $\left(\mathrm{X}_{1}\right)$ dan keselamatan kerja $\left(\mathrm{X}_{2}\right)$ memberikan sumbangan pengaruh sebesar 83,2\% terhadap produktivitas kerja (Y). Sedangkan sisanya sebesar $16,8 \%$ dipengaruhi oleh variabel yang lain yang tidak masuk dalam penelitian ini seperti motivasi, iklim organisasi, lingkungan kerja, semangat kerja, dll.

Dengan menggunakan tingkat keyakinan 95\%, a=5\%, df1 (jumlah variabel-1)=2 dan df2 (n-k-1) atau(50-2$1)=47$. Nilai $F_{\text {hitung }}$ adalah sebesar 116,215 dengan tingkat signifikansi 0,000. Menurut Sugiyono (2014, h.295) jika $F_{\text {hitung }}>F_{\text {tabel }}$ maka Ho ditolak dan Ha diterima. Sebaliknya jika $F_{\text {hitung }}<$ $F_{\text {tabel }}$ maka Ho diterima dan Ha ditolak. Pada penelitian ini ternyata $F_{\text {hitung }}$ $\left(116,215>\mathrm{F}_{\text {tabel }}(3,20)\right.$, artinya Ho ditolak dan $\mathrm{Ha}$ diterima. Hal ini menunjukkan ada pengaruh yang signifikan antara kompensasi dan keselamatan kerja.

i. Pengaruh Kompensasi (X) terhadap Produktivitas Kerja Pegawai (Y) Pada PT. Musirawas Lestari Makmur Kabupaten Musi Rawas. 
Dari hasil perhitungan regresi linier sederhana, diperoleh nilai kompensasi $b_{1}=0,760$ sedangkan nilai $a=9,342$. Kemudian nilai tersebut dimasukkan kedalam persamaan regresi linear sederhana yaitu $\mathrm{Y}=9,342+$ $0,760 \mathrm{X}_{1}$ yang artinya nilai konstan $\mathrm{a}=$ 9,342 jika motivasi tidak ada perubahan atau nilainya nol maka nilai variabel produktivitas kerja adalah sebesar 9,342 .

Koefisien regresi kompensasi sebesar $b_{1}=0,760$ menyatakan bahwa setiap peningkatan kompensasi sebesar satu satuan maka hal tersebut akan meningkatkan produktivitas kerja sebesar 0,760. Sebaliknya, setiap penurunan kompensasi sebesar satu satuan maka hal tersebut akan menurunkan produktivitas kerja sebesar 0,760 .

Nilai koefisien korelasi $\mathrm{R}$ sebesar 0,908. Hal ini menunjukkan bahwa kompensasi $\left(\mathrm{X}_{1}\right)$ dengan produktivitas kerja (Y) mempunyai hubungan sangat kuat. Sedangkan arah hubungan adalah positif karena nilai $\mathrm{R}$ positif.

Dari perhitungan uji t diketahui hasil $t_{\text {hitung }}$ menunjukkan bahwa variabel kompensasi $\left(\mathrm{X}_{1}\right)$ mempunyai nilai $\mathrm{t}_{\text {hitung }}$ sebesar 14,365 lebih besar dibandingkan dengan nilai $t_{\text {tabel }}$ pada taraf nyata sebesar 1,29871 atau dapat dikatakan kompensasi $\left(\mathrm{X}_{1}\right)$ berpengaruh signifikan terhadap produktivitas kerja (Y).

\section{j. Pengaruh Keselamatan Kerja (X) Produktivitas Kerja Pegawai (Y) Pada PT. Musirawas Lestari Makmur Kabupaten Musi Rawas.}

Dari hasil perhitungan regresi linier sederhana, maka diperoleh nilai $\mathrm{b}_{2}=0,583$ sedangkan nilai $\mathrm{a}=16,646$. Kemudian nilai tersebut dimasukkan kedalam persamaan regresi linear sederhana yaitu $\mathrm{Y}=16,646+0,583 \mathrm{X}_{2}$ yang artinya jika keselamatan kerja tidak ada perubahan atau nilainya nol maka nilai variabel produktivitas kerja adalah sebesar 16,646.

Koefisien regresi keselamatan kerja sebesar $b_{2}=0,583$ menyatakan bahwa setiap peningkatan keselamatan kerja sebesar satu satuan maka hal tersebut akan meningkatkan produktivitas kerja sebesar 0,583. Sebaliknya, setiap penurunan keselamatan kerja sebesar satu satuan maka hal tersebut akan menurunkan produktivitas kerja sebesar 0,583.

Nilai koefisien korelasi $\mathrm{R}$ sebesar 0,731. Hal ini menunjukkan bahwa keselamatan kerja $\left(\mathrm{X}_{2}\right)$ dengan produktivitas kerja (Y) mempunyai hubungan kuat. Sedangkan arah hubungan adalah positif karena nilai $\mathrm{R}$ positif.

Dari perhitungan uji t diketahui $t_{\text {hitung }}$ menunjukkan bahwa variabel keselamatan kerja $\left(\mathrm{X}_{2}\right)$ mempunyai nilai $t_{\text {hitung }}$ sebesar 7,411 lebih besar dibandingkan dengan nilai $t_{\text {tabel }}$ pada taraf nyata sebesar 1,29871 atau dapat dikatakan keselamatan kerja $\left(\mathrm{X}_{2}\right)$ berpengaruh signifikan terhadap produktivitas kerja (Y).

\section{PENUTUP}

\section{Kesimpulan}

Berdasarkan penelitian dari hasil analisis sesuai dengan tujuan penelitian, maka peneliti dapat menyimpulkan bahwa :

1. Hasil perhitungan Anova (Uji F), terlihat bahwa nilai Nilai $F_{\text {hitung }}$ adalah sebesar 24,252 dengan tingkat signifikansi 0,000 . Menurut Sugiyono (2014, h.295) jika $F_{\text {hitung }}>$

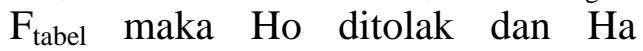
diterima. Sebaliknya jika $F_{\text {hitung }}<$ $\mathrm{F}_{\text {tabel }}$ maka Ho diterima dan $\mathrm{Ha}$ ditolak. Pada penelitian ini ternyata $\mathrm{F}_{\text {hitung }}\left(116,215>\mathrm{F}_{\text {tabel }}(3,20)\right.$, artinya Ho ditolak dan Ha diterima. Hal ini menunjukkan ada pengaruh yang 
signifikan antara kompensasi dan keselamatan kerja terhadap produktivitas kerja. Nilai koefisien determinasi atau $\mathrm{R}^{2}$ sebesar 0,832 atau $83,2 \%$. Nilai tersebut memberi pengertian bahwa kompensasi $\left(\mathrm{X}_{1}\right)$ dan keselamatan kerja $\left(\mathrm{X}_{2}\right)$ memberikan sumbangan pengaruh sebesar $83,2 \%$ terhadap produktivitas kerja (Y).

2. Dari perhitungan uji t diketahui hasil $t_{\text {hitung }}$ menunjukkan bahwa variabel kompensasi $\left(\mathrm{X}_{1}\right)$ mempunyai nilai $t_{\text {hitung }}$ sebesar 14,365 lebih besar dibandingkan dengan nilai $t_{\text {tabel }}$ pada taraf nyata sebesar 1,29871 atau dapat dikatakan kompensasi $\left(\mathrm{X}_{1}\right)$ berpengaruh signifikan terhadap produktivitas kerja (Y). Koefisien regresi kompensasi sebesar $b_{1}=0,760$ menyatakan bahwa setiap peningkatan kompensasi sebesar satu satuan maka hal tersebut akan meningkatkan produktivitas kerja sebesar 0,760. Sebaliknya, setiap penurunan kompensasi sebesar satu satuan maka hal tersebut akan menurunkan produktivitas kerja sebesar 0,760. Jadi pengaruh kompensasi terhadap produktivitas kerja sebesar $76 \%$.

3. Dari perhitungan uji t diketahui $t_{\text {hitung }}$ menunjukkan bahwa variabel keselamatan kerja $\left(\mathrm{X}_{2}\right)$ mempunyai nilai $t_{\text {hitung }}$ sebesar 7,411 lebih besar dibandingkan dengan nilai $t_{\text {tabel }}$ pada taraf nyata sebesar 1,29871 atau dapat dikatakan keselamatan kerja $\left(\mathrm{X}_{2}\right)$ berpengaruh signifikan terhadap produktivitas kerja (Y). Koefisien regresi keselamatan kerja sebesar $\mathrm{b}_{2}=0,583$ menyatakan bahwa setiap peningkatan keselamatan kerja sebesar satu satuan maka hal tersebut akan meningkatkan produktivitas kerja sebesar 0,583. Sebaliknya, setiap penurunan keselamatan kerja sebesar satu satuan maka hal tersebut akan menurunkan produktivitas kerja sebesar 0,583. Jadi pengaruh keselamatan kerja terhadap produktivitas kerja sebesar 58,3\%.

\section{Saran}

Dari hasil penelitian ini diberikan beberapa saran, antara lain :

1. Hendaknya pemberian kompensasi harus adil dan setingkat dengan apa yang dikerjakan oleh karyawan sehingga tidak terjadi kesenjangan antara sesama karyawan.

2. Sebaiknya sering dilakukan sosialisasi mengenai cara penggunaan peralatan dengan baik dan benar.

3. Sebaiknya sering dilakukan sosialisasi aturan tentang penggunaan alat keamanan diri sendiri dalam bekerja.

DAFTAR PUSTAKA

Arikunto, Suharsimi. (2006). Prosedur Penelitian Suatu Pendekatan Praktik. PT Rineka Cipta

Bayu Ramdan Herdianto. (2014). Pengaruh keselamatan dan kesehatan kerja (K3) terhadap motivasi kerja karyawan (Studi pada Karyawan bagian Drilling \& Oilfield Services PT Elnusa Tbk. Jakarta). Jurnal.

Fahmi, Irham. (2012). Manajemen. Bandung : Penerbit Alfabeta.

Edy Sutrisno. (2014). Manajemen Sumber Daya Manusia. Cetakan ke Enam. Penerbit : Kencana Prenada Media Group.

Hasibuan, Malayu. (2009). Manajemen Sumberdaya Manusia. Edisi Revisi. Cetakan Kesebelas. Jakarta : Bumi Aksara.

Ni Kadek Yuliandari. (2014). Produktivitas Kerja Karyawan Bagian Loster Pada UD Yuri Desa Pangkung Buluh Kecamatan Melaya Kabupaten Jembrana. Jurnal. 
Panggabean, Mutiara S. (2004). Manajemen Sumber Daya Manusia. Cetakan Pertama. Jakarta: Ghalia Indonesia

Priyatno, Duwi. (2013). Analisis Korelasi, Regresi dan multivariate dengan SPSS. Yogyakarta : Penerbit Gava Media.

SPSS 17.0. Statistical Product And Service Solution. Version 22.0 For Windows.

Sugiyono. (2014). Statistik Untuk Penelitian. Cetakan ke Dua puluh empat. Bandung : Alfabeta

Vicky Frestiani Dewi. (2014). Pengaruh Kompensasi terhadap Produktivitas Kerja Pegawai Pada Kantor Dinas Perindustrian, Perdangan, Koperasi dan UMKM Samarinda. Jurnal.

Wibowo. (2012). Manajemen Kinerja. Cetakan Ke Tiga. Jakarta : PT. Raja Grafindo Persada. 